\title{
ENIGE OPMERKINGEN MET BETREKKING TOT HET VOORONTWERP GEDRAGS- EN BEROEPSREGELS
}

\author{
door Prof. Drs. G. L. Groeneveld en \\ Prof. Drs. A. A. de Jong
}

\section{Het vertrouwenselement}

De ontwikkeling binnen het Nederlands Instituut van Accountants heeft er toe geleid, dat dit geen instituut geworden is van uitsluitend accountants die een openbare accountantspraktijk uitoefenen, maar dat zowel examen als lidmaatschap toegankelijk zijn voor eenieder die aan de gestelde deskundigheidseisen heeft voldaan. Die situatie werd door de Wet op de Registeraccountants bestendigd in het Nederlands Instituut van Registeraccountants. De reglementering van dé arbeid was van oudsher specifiek gericht op de uitoefening van de accountantspraktijk, men mag wel zeggen van de openbare accountantspraktijk. Dit wordt meer en meer als bezwaarlijk ondervonden door het toenemend aantal van hen die aan de accountantspraktijk geen deel hebben.

De herziening van de R.B.R. zou ook dit bezwaar moeten ondervangen. Dienovereenkomstig onderscheidt het voorontwerp inderdaad afzonderlijke regels die voor elke registeraccountant gelden en regels die gelden voor registeraccountants die optreden hetzij als accountant, hetzij als openbaar accountant. In het voorontwerp wordt daartoe echter geen categorale indeling van de registeraccountants gemaakt, maar veeleer een functionele. Overeenkomstig de moderne maatschappelijke tendenties tot grensvervaging en alternatief optreden gaat het voorontwerp er van uit, dat in beginsel aan iedere registeraccountant elk professioneel optreden is toegestaan, mits hij zich houdt aan de regels die voor elke wijze van optreden zijn gesteld. Onder meer is daarvan een aantal zeer ruime begripsbepalingen het gevolg. Te noemen zijn de niet-afbakening van de grenzen van het accountantsberoep, de regeling dat elke uiting van een registeraccountant wordt geacht te zijn gedaan in de accountantsfunctie, de afwijzing van enigerlei onderscheiding tussen controlefunctie en adviesfunctie en de uitbreiding van het begrip verklaring tot mededelingen die uit een advies bestaan.

Het wil ons voorkomen dat deze stellingname het meest belangrijke facet der herziening vormt, alsook dat daaraan in de voorafgaande gedachtenwisseling tot dusverre onvoldoende aandacht is geschonken. De konsekwenties zijn ingrijpend. Nu de openbaar accountant als categorie in de reglementering verdwijnt en diens functie wordt vervangen door een (mogelijk willekeurig) optreden als zodanig, is de vrees dat daarmede gewroet wordt aan de wortels van de vrije beroepsuitoefening niet denkbeeldig. Zoals uit de toelichting blijkt is het b.v. in deze visie mogelijk te stellen dat het van een te beperkt inzicht zou getuigen indien men van oordeel zou zijn dat alleen de vorm ,,vrij beroep" voldoende waarborgen voor onafhankelijkheid geeft en dat andere strukturen daarvoor een tenminste even grote waarborg scheppen. De gevolgen daarvan zijn o.i. niet te overzien.

Evenmin als het voorontwerp de openbaar accountant als figuur, categorie of functie kent (de reglementering wordt verbonden aan de verrichting), kent 
het de registeraccountant die het accountantsberoep niet uitoefent, ook al kan dit woordgebruik in het voorontwerp niet altijd worden ontgaan. Voor deze categorie gelden de algemene bepalingen uit hoofdstuk I. Als gedragsregels zijn het er drie. Schuiven we de eerlijkheid en nauwgezetheid als archaisch terzijde, dan blijven er twee: de registeraccountant mag geen groter vertrouwen wekken dan zijn functie en werkzaamheden rechtvaardigen en hij mag over vertrouwelijke aangelegenheden geen andere mededelingen doen dan de vervulling van zijn functie vereist.

Het voorontwerp motiveert deze regeling met de stelling, dat het maatschappelijk verkeer in een registeraccountant, die in een andere functie dan als accountant optreedt, een groter vertrouwen stelt dan in de gediplomeerde die zich niet in het register heeft doen inschrijven en overigens in dezelfde omstandigheden verkeert. Nu zijn wij in de eerste plaats van mening dat dit niet zo is, maar daarover kan men van mening verschillen. Belangrijker achten wij, dat hier elementen van de openbare beroepsuitoefening naar de niet aan die beroepsuitoefening deelnemende collega's worden verschoven.

De stelling dat de accountant geen groter vertrouwen mag wekken dan zijn arbeid rechtvaardigt, is een element uit de vertrouwenstheorie. Deze theorie geeft een verklaring voor de differentiatie van de controlerende functie van de accountant tot een vrij beroep. De theorie legt het theoretisch fundament onder de functie van de openbare accountant. Ze laat zien hoe groot de rol is die het maatschappelijk vertrouwen in het accountantsoordeel speelt en hoe dit alleen kan spelen wanneer dit oordeel in vrijheid en onafhankelijkheid wordt afgegeven.

Een der conclusies uit deze opvatting is, dat het vertrouwen door de verrichte arbeid moet zijn gedekt en dat de accountant geen groter vertrouwen mag wekken dan met zijn arbeid overeenkomt. Aldus wordt de theorie ook tot de kwantitatieve basis voor de verrichtingen van de controlerende accountant.

In functies buiten de beroepsuitoefening is van dit specifieke vertrouwenselement geen sprake. De gehele probleemstelling ontbreekt. In besturende functies is het vertrouwenselement geen ander dan dat van iedere andere medewerker. Wel kan men stellen, dat het vertrouwen met het niveau van de arbeidsverrichting groeit en uit dien hoofde voor de bestuurder met het deskundigheidskenmerk van de registeraccountant tot een hoog niveau zal reiken. Maar dit is een vertrouwen van geheel andere aard. Het is niet specifiek voor de accountant en geeft geen kwantitatieve grondslag voor zijn arbeid.

\section{De geheimhouding}

Genoeg over de vertrouwensregel, die wij, gezien de parallelliteit tussen de artikelen 40 en 50 , moesten toelichten ter inleiding van een praatje over de geheimhouding. Die parallelliteit is o.i. gecreëerd doordat beide artikelen specifieke betekenis hebben voor de openbare accountant en niet voor de man met het deskundigheidskenmerk sans plus. Toch worden de artikelen voorgesteld voor alle personen zich noemende en schrijvende registeraccountant. 
De tekst van het voorontwerp wijkt ten aanzien van de geheimhouding in twee opzichten af van het vergelijkbare artikel 17 van de R.B.R. De formulering van de R.B.R., ,hetgeen bij het verrichten zijner werkzaamheden te zijner kennis is gekomen, voor zover dit een vertrouwelijk karakter draagt" is vervangen door ,vertrouwelijke aangelegenheden". Aangezien deze laatste eveneens bij het verrichten zijner werkzaamheden te zijner kennis moeten zijn gekomen, resteert een verschil tussen ,,vertrouwelijk karakter” en ,vertrouwelijke aangelegenheid". De betekenis van deze wijziging ontgaat ons tot dusverre, waarmede ook niets kwaads gezegd wil zijn. Volgens het voorontwerp reikt ,vertrouwelijke aangelegenheden" verder.

Van groter belang lijkt ons de wijziging van „opdracht" in „functie”. Het is duidelijk dat deze wijziging noodzakelijk is, indien men de plicht tot geheimhouding van de openbaar accountant uitbreidt tot alle registeraccountants die wel een functie vervullen, maar wier functies niet door specifieke „opdrachten" worden geconstitueerd.

N.o.m. brengt de uitbreiding zijn bezwaar mee. De bepaling is wellicht bedoeld als gebodsbepaling (Zwijgplicht). Dit is echter het minst belangrijke aspekt van de zaak. Als ge- of verbodsbepaling is ze min of meer vanzelfsprekend - waarmee niet gezegd wil worden dat de reglementering geen vanzelfsprekendheden zou mogen bevatten. Wij zien echter een veel grotere betekenis van de bepaling in het aspekt, dat ze de accountant ook bescherming moet bieden. Hij moet zich behalve op de wet ook op zijn eigen reglementaire struktuur kunnen beroepen om zich tot zwijgen te beperken (Zwijgrecht).

En dan bicdt n.o.m. de afgrenzing van ,functie" van de accountant minder bescherming dan die van ,opdracht”. Indien b.v. een met de controle van de jaarrekening belaste accountant in een procedure zou worden gevraagd zich uit te spreken over de kwaliteiten van de administratief directeur, kan hij zich met een beroep op de grenzen van zijn opdracht op zijn zwijgplicht resp. zwijgrecht beroepen. Verlegt men de grens naar de functie, dan wordt dit twijfelachtig, gezien ook de ruime begripsbepalingen van de voorgestelde reglementering, waarin men noch voor beroep noch functie grenzen trekken wil.

Het voorontwerp geeft later een andere reden voor de wijziging in „functie". Het spreekt van de mogelijkheid dat een hoger belang dan dat van de gecontroleerde, verdergaande opheffing van de geheimhoudingsplicht noodzakelijk kan maken (blz. 29). Ter plaatse wordt dit niet toegelicht. Mogelijk wordt het hogere belang gezien in de plicht tot het plegen van collegiaal overleg en het doen van de vcreiste mededelingen in geval de opdrachtgever van accountant verandert. Bij een beperking tot de opdracht zouden letterlijk (zo zegt de toelichting) geen inlichtingen kunnen worden gegeven, hetgeen bij een verruiming tot de functic wel zou kunnen. N.o.m. behoeft voor dit geval de bescherming, die voor de accountant in het beroepsgeheim is gelegen, niet te worden aangetast. Deze uitwisseling of mededeling is een beroepstechnisch gegeven, dat als zodanig bekend moet zijn en aanvaard door het maatschappelijk verkeer, desnoods bij de aanvaarding van de opdracht moet zijn medegedeeld. Dit moet niet op deze wijze via de geheimhoudingsplicht worden geregeld. Het ware voldoende dat het maatschappe- 
lijk verkeer bekend zou zijn met de inhoud van de artikelen 192/194.

Het zal na het voorafgaande duidelijk zijn dat ons kernbezwaar zich ook ten aanzien van het punt geheimhouding richt tot de uitbreiding van het gebod tot allen die in het register zijn ingeschreven, ongeacht de functie die zij vervullen. De reglementering moet dienen ter onderstreping, bevestiging van plicht, en daarnaast van recht tot geheimhouding van vertrouwelijke gegevens. Dit is primair een recht van het openbaar beroep. Het wordt naar maatschappelijke opvattingen toegekend aan die categorieën van vrij en openbaar in de maatschappij opererende functionarissen, welker recht op geheimhouding hoger wordt gewaardeerd dan het recht van de rechter op volledige voorlichting.

De toelichting ziet dat eigenlijk wel. Ze spreekt althans van verschillende grenzen van de geheimhoudingsplicht voor verschillende functies. Een van zijn essentiële plichten wordt de geheimhoudingsplicht voor de registeraccountant die als (openbaar)-accountant optreedt. Dáár kan alleen stringente handhaving tot een doeltreffend fungeren leiden (blz. 37). Inderdaad; maar evenzeer moet de grens worden getrokken, dat de bestuurder met een geregistreerd accountantsdiploma geen hogere verplichtingen van vertrouwen en geheimhouding heeft dan uit zijn functie voortvloeien. Deze kunnen groot genoeg zijn. Maar zo hij die schendt, is er geen plaats voor afzonderlijke berechting door de beroepsrechtspraak. De registeraccountant die het beroep niet uitoefent, kan maar voor één artikel uit het eerste hoofdstuk staan: dat hij zich zal onthouden van al hetgeen schadelijk is voor de eer van de stand der registeraccountants.

De keerzijde van geheimhoudingsplicht en -recht wordt gevormd door spreekplicht en spreekrecht. Het voorontwerp doet een voorzichtige stap in de richting van de invoering van een spreekrecht. De mededeling moet betreffen een voor de vervulling van de functie vereiste mededeling en het is de accountant verboden de openbaarmaking daarvan anders dan na overleg met het bestuur te doen geschieden.

Een der gevallen waarop het spreekrecht betrekking heeft is dat van artikel 145 , volgens hetwelk de accountant een openbaarmaking van zijn verklaring die zonder zijn voorafgaande schriftelijke toestemming is geschied, kan redresseren. Akkoord. Voor het overige is de toelichting vrij summier. Het wil ons voorkomen, dat de materie van het spreekrecht te belangrijk is en nog te weinig ontwikkeld om in zo'n vage algemeenheid in de gedragsregels te kunnen worden opgenomen. Wij weten nu niet waar het spreekrecht al dan niet betrekking op kan hebben. En naast het uitoefenen van het spreekrecht bestaat het aspekt van het zwijgen daar waar anderen menen dat gesproken had moeten zijn.

Het overleg met het bestuur kan de gebreken van artikel 51 niet verhelpen. In de eerste plaats is het bestuur niet het geschikte orgaan. Het is gekozen om zijn besturende kwaliteiten, niet als een college van wijze mannen, dat in alle rust en bezonkenheid zal oordelen over mogelijk de lastigste gevallen die zich in de beroepsuitoefening kunnen voordoen. In de tweede plaats is de verantwoordelijkheid voor dit advies werkelijk niet bepaalbaar, noch de bete- 
kenis daarvan voor de verantwoordelijkheid van de betrokken accountant.

Vermelden wij tenslotte dat artikel 53 inhoudt, dat de registeraccountant een opdracht tot het doen van vertrouwelijke mededelingen, anders dan die welke de vervulling van zijn functie vereist, niet zonder meer behoeft te aanvaarden. Een fraai voorbeeld van een beschermende bepaling voor de registeraccountant, waarmede ondergetekenden volledig instemmen.

\section{De collectieve of medeverantwoordelijkheid}

Bij de ontwikkeling van de beroepsuitoefening in maatschapsverband werd de accountant zich ervan bewust, dat hij niet alleen persoonlijk verantwoordelijk is voor de door hem verrichte arbeid en de mededelingen omtrent de uitkomst daarvan. Hij zag in dat het gemeenschappelijk gewekte vertrouwen de belofte inhoudt van een gemeenschappelijke verantwoordelijkheid. Deze verantwoordelijkheid zou minder inhouden dan de individuele verantwoordelijkheid en met name beperkt zijn tot een collectieve verantwoordelijkheid voor de algemene grondslagen van de onderzoekingen.

Voor de beroepsuitoefening in maatschapsverband van de controlerende accountant was dit een vrij eenvoudige aangelegenheid, maar ook hier werd de situatie weldra meer ingewikkeld. Andere samenwerkingsverbanden, de verhoudingen bij binnen- en buitenlands optreden, samenwerkingsverhoudingen met deskundigen van andere disciplines, riepen vele vragen op naar karakter, grondslag, grenzen en realisatiemogelijkheden van de gemeenschappelijk gewekte verantwoordelijkheid.

Het voorontwerp vervangt de aloude aanduiding van collectieve verantwoordelijkheid door die van medeverantwoordelijkheid, een wijziging die onvermijdelijk lijkt, nu enerzijds de reikwijdte verder moet worden getrokken dan het collectief van in maatschap werkende beroepsgenoten, anderzijds de inhoud minder moet zijn dan in dat collectief.

Criterium wordt terecht het optreden als openbaar accountant onder gemeenschappelijke naam met een ander (artikel 170). Direkt daarop getuigt het volgende artikel van de bijna stormachtige nieuwe ontwikkeling, doordat het de voorwaarden regelt waaronder onder gemeenschappelijke naam mag worden opgetreden. Het meest interessant daarvan is lid b. Het laat via een dispensatieregeling van het bestuur de mogelijkheid open onder gemeenschappelijke naam op te treden met niet-registeraccountants, w.o. buitenlandse accountants of beofenaren van andere beroepen zoals belastingadviseurs en organisatie-adviseurs.

Grondslag voor het dispensatiebeleid zal zijn de reële mogelijkheid om de ontstaande medeverantwoordelijkheid te kunnen dragen. Dit wordt aldus uitgewerkt, dat de samenwerkende niet-registeraccountants zullen verklaren de G.B.R. en de U.G.B.R. in acht te zullen nemen en dat zij onderworpen zullen zijn aan een repressief toezicht, vergelijkbaar met het tuchtrecht waaraan de accountant is onderworpen. Voor de hier te lande samenwerkende buitenlandse accountants zou de tuchtrech tspraak in handen moeten zijn van colleges die een volledige personele unie kennen met de bestaande raden van tucht en beroep. 
Dit alles is uiteraard nog vrij vaag en onuitgewerkt. Het probleem van het reeds onderworpen zijn aan de tuchtrechtspraak van een andere organisatie van beoefenaren van een vrij beroep wordt aangeduid maar niet uitgewerkt. Gebleven is (artikel 172), dat de medeverantwoordelijkheid zich niet verder zal uitstrekken dan tot de algemene grondslagen van de arbeid van de anderen (vroeger: ,algemene grondslagen van de onderzoekingen"). In het geval van optreden met een ander dan een registeraccountant strekken de maatregelen tot het dragen van de voor diens arbeid bestaande medeverantwoordelijkheid zich tenminste zo ver uit als in de dispensatiemededeling van het bestuur is vastgesteld. Het voorontwerp verwacht daarin een grote variatie.

Het voorontwerp gaat er van uit, dat adequate maatregelen mogelijk zijn voor het dragen van medeverantwoordelijkheid voor het handelen onder gemeenschappelijke naam door anderen dan registeraccountants, met name door beoefenaren van andere verwante beroepen (blz. 24).

Het is zeer de vraag of het voorontwerp hierin niet te optimistisch is. In de beoordeling van de arbeid van beoefenaren van een ander beroep - b.v. organisatie-adviseurs zoals ingenieur, psycholoog, socioloog e.d. - is de grens zeer spoedig bereikt. Zelfs systematiek en zorgvuldigheid laten zich moeilijk beoordelen. De ,weloverwogenheid en aannemelijkheid" van collega Van Belkum (januari-nummer van De Accountant) nog veel moeilijker.

In De Accountant van januari jl. wordt gesproken van het in acht nemen van ,spelregels", die dan een aanvaardbare basis zouden kunnen zijn om de medeverantwoordelijkheid van de gezamenlijk verrichte adviesarbeid te kunnen dragen. Inderdaad, op spelregels zal het neerkomen. Maar leveren deze niet een te smalle basis voor het dragen van medeverantwoordelijkheid?

Het voorontwerp tracht wel de grenzen van de medeverantwoordelijkheid nader te omlijnen, maar blijft daarbij toch erg in het vage. Het spreekt onomwonden uit, dat men geen behoefte heeft aan een begripsafbakening van de ,algemene grondslagen" van de arbeid van de ander.

Met betrekking tot de medeverantwoordelijkheid van de medewerker wordt gesteld, dat deze zich niet verder uitstrekt dan hetgeen redelijkerwijs van hem kan worden verwacht. Voldoende acht men het, dat hij niet aanvaardt dat hij buiten de beleidsvorming wordt gehouden inzake de maatregelen tot het dragen van de gemeenschappelijke verantwoordelijkheid. Dit is wel wat weinig voor iemand die volgens art. $22 \mathrm{e}$ geacht wordt als openbaar accountant op te treden, ofschoon hij in dienstbetrekking staat tot een andere als openbaar accountant optredende registeraccountant. Of zou dit laatste wat overtrokken zijn, als gevolg van een te ver gaande grensvervaging b.v.?

De bepaling van de verantwoordelijkheid bij optreden onder gemeenschappelijke naam met een ander dan een registeraccountant wordt gedelegeerd aan het steeds machtiger wordend bestuur, in het kader van de opgelegde dispensatie-voorwaarden. Een noviteit is de bevoegdheid die het bestuur krijgt met betrekking tot de naamgeving van een samenwerking, die ,ondubbelzinnig onderscheidend" zal moeten zijn.

Resumerend kan worden gesteld, dat de voorstellen met betrekking tot de regeling van de collectieve verantwoordelijkheid met name van betekenis 
blijken te zijn daar waar de gevolgen voor die verantwoordelijkheid worden geregeld of waar $\mathrm{zij}$ de erkenning van nieuwe vormen van samenwerking betreffen, hetzij in andere rechtsvorm, hetzij met buitenlandse accountants of met beoefenaren van andere vrije beroepen. Belangrijker nog dan de regeling der medeverantwoordelijkheid, ofschoon daarmede zeer nauw samenhangend, is de vraag naar de gewenstheid van laatstgenoemde associaties als zodanig. Over de wenselijkheid van mogelijke associatie met een buitenlandse accountant heeft de ledenvergadering zich afzonderlijk uitgesproken. De vraag rijst, of het niet noodzakelijk is, dat de ledenvergadering gelegenheid krijgt zich eveneens over de andere associatievormen afzonderlijk uit te spreken en de toelating daarvan niet zonder meer in de reglementsherziening mede te nemen. Bulletin no. 6 der C.H.B. was nog van mening dat de multidisciplinaire maatschap thans nog niet kan worden gerealiseerd. En zoals steeds moeten wij niet verzuimen terug te zien naar het standpunt dat Limperg ooit heeft ingenomen en dat hij in dit vraagstuk nog in 1957 heeft geformuleerd. Nog recent is daarnaar door P. J. H. J. Bos verwezen. ${ }^{1}$ )

Limperg meende, dat het maatschappelijk verkeer niet in staat zou zijn, het heterogene karakter van de deskundigheden te onderscheiden en vreesde, dat de vrijheid tot vorming van de beoogde combinaties op den duur schadelijk zou zijn voor de functie van de accountant. Aldus zien wij, dat er duidelijk tenminste twee facetten zijn aan de erkenning van de multi-disciplinaire samenwerking. Enerzijds is er de visie van hen die de veelzijdige ontplooiing van de organisatieproblematiek wensen te volgen en gezien hun deskundigheden en huidige fungeren ook in hun arbeid willen mee beleven. $\mathrm{Z}_{\mathrm{ij}}$ zouden het afzien daarvan als een verschraling ondervinden. Anderzijds zijn er die problemen zien in de deskundigheids- en de verantwoordelijkheidsbegrenzing. $\mathrm{Zij}$ vrezen een verwatering van de controlerende accountantsfunctie in het veelzijdige dienstenpakket dat door een heterogeen samengesteld team zou worden aangeboden. Een alternatief tussen verschraling en verwatering is geen aanlokkelijk vooruitzicht. Moge dit een aansporing zijn om behoedzaam te opereren.

\section{De accountant in dienstbetrekking (de interne accountant)}

De verhouding tussen de openbare en interne accountant is door de jaren heen steeds een belangwekkend onderwerp binnen het beroep geweest. Duidelijk is zonder meer dat het tussen beiden niet gaat om een verschil in vaktechnische bekwaamheid (zie Goudeket 1939) maar dat het gaat om een verschil in functie.

De interne accountant ontleent zijn functie aan de leiding; de functie is in beginsel een van de leiding afhankelijke. Anderzijds weet hij zich accountant en zal tot een onafhankelijk oordeel moeten komen gebaseerd op deskundig verrichte arbeid. Door zijn functionele gebondenheid aan de leiding van de onderneming is hij echter niet de aangewezen man om aan de behoefte van het maatschappelijk verkeer te voldoen. Het verkeer vraagt om een onaf-

1) P. J. H. J. Bos. Collectieve en gemeenschappelijke verantwoordelijkheid. Bijdrage van november 1972 in het Handboek Accountancy.

$m a b$ blz. 112 
hankelijk oordeel en dit kan alleen gegeven worden door de openbare accountant.

Dit is een algemeen aanvaard standpunt, wat overigens niet betekent dat hiermede het vraagstuk is opgelost. De vraag blijft namelijk nog onbeantwoord waar de grenzen liggen waarbuiten de interne accountant in het maatschappelijk verkeer zou komen. Reeds jaren terug is men naarstig naar deze grenzen gaan zoeken. Opvallend daarbij is dat men zoekend naar deze grenzen niet steeds het algemeen aanvaarde principe in het oog heeft gehouden dat het verkeer behoefte heeft aan een onafhankelijk oordeel.

Alvorens tot een bespreking te komen van het resultaat van de C.H.B. een korte beschouwing over reeds eerder gedane pogingen te komen tot een afgrenzing van het werkterrein van de interne accountant. Wij staan stil bij het C.A.B. rapport van 1954, het in 1956 opgenomen art. 5 in de Ereregelen in aansluiting met art. 21 R.B.R. en het artikel van P. C. Louwers in de encyclopedie van de bedrijfseconomie deel $\mathrm{V}$.

- Het genoemde C.A.B. rapport heeft betrekking op enkele vragen samenhangende met artikel 3 van de Ereregelen. Artikel 3 lid $3 b$ liet namelijk de (hoewel niet bedoelde) mogelijkheid voor de interne accountant open verklaringen af te geven ten behoeve van het maatschappelijk verkeer. Dit kon uiteraard in de ogen van de commissie geen genade vinden en ze achtte een wijziging van de bestaande reglementering op dit punt wenselijk.

De moeilijkheid was echter hoe te bepalen waar de interne accountant nog binnen zijn functie blijft en waar hij, door in het maatschappelijk verkeer te komen, de functie van de openbare accountant zou gaan uitoefenen.

De verklaring kan uiteraard verstrekt worden aan de directie en de openbare accountant, maar ook aan de commissarissen, bankier, aan de weinig talrijke aandeelhouders of ook aan een iets groter aantal aandeelhouders in een familiezaak? Dit alles in aanmerking nemende achtte de commissie het niet mogelijk een voor alle gevallen bruikbare afbakening te geven van het gebied, waarbuiten de verklaring van de interne accountant niet meer op haar plaats moet worden geacht en een voorstel tot reglementswijziging bleef achterwege. Wel gaf de commissie in overweging dat het Bestuur, indien het overschrijding van de grenzen vaststelt, in collegiaal overleg treedt met de interne accountant.

Dit rapport heeft ons dus niet veel verder gebracht. Wel komt er duidelijk in tot uiting dat het besloten verkeer wellicht binnen de grenzen van de interne accountant zou kunnen liggen en dat het ook door de commissie aanvaarde beginsel dat het maatschappelijk verkeer behoefte heeft aan een onafhankelijk oordeel bij het trekken van deze grenzen de mist in gaat.

- In december 1956 zijn de Ereregelen gewijzigd. Art. 5 kwam als volgt te luiden: (5.1)

„Het is de leden die niet in de accountantspraktijk werkzaam zijn verboden een verklaring af te geven anders dan aan hun werkgever. Zij dragen er zorg voor, dat hun verklaringen niet worden openbaar gemaakt".

In de regelen beroepsuitoefening van 1963 is een vrijwel analoge bepaling opgenomen (art. 21). 
Met de wijziging van art. 5 van de Ereregelen is een wat strakkere weg bewandeld. De weg is namelijk duidelijk aangegeven, nl. de verklaring wordt bij uitsluiting gegeven aan de opdrachtgever.. Wel blijft ook hier de vraag wat onder openbaar maken moet worden verstaan, maar gezien de toelichting op art. 21 zijn wij geneigd er van uit te gaan dat overschrijding van de grenzen van de onderneming beperkt blijft tot bankier en rijksaccountant.

Van het in het C.A.B. rapport opdoemende uitgebreidere besloten verkeer is hier geen sprake.

- Louwers brengt in zijn genoemd artikel het besloten verkeer weer ter sprake. „Een verklaring die in het besloten maatschappelijk verkeer blijft, moet geacht worden niet openbaar te zijn gemaakt". Ook hier weer de vraag, waar ligt de grens. Louwers ziet de toelichting op artikel 21 lid 4 als een opening hiervoor. Wij dachten niet dat dit de bedoeling is geweest.

Belangrijker is dat ook Louwers bij het maken van het onderscheid tussen besloten en openbaar maatschappelijk verkeer een eerder gedane uitlating vergeet, met name de zin ,,het maatschappelijk verkeer heeft behoefte aan een onafhankelijk oordeel". Dit geldt zowel voor het openbaar als voor het besloten maatschappelijk verkeer.

- Sluit Louwers enerzijds aan op de - zij het niet expliciet uitgesproken gedachten van het C.A.B. rapport, anderzijds zien wij in hem een voorloper van de C.H.B. Maar de C.H.B. is in zijn ontwerp nog aanmerkelijk verder gegaan. Bleef Louwers nog binnen het raam van art. 21 , de C.H.B. behoefde dit niet meer te doen, want zij hebben de inhoud van art. 21 sub 1 niet meer in het ontwerp opgenomen. De verbodsbepaling verklaringen af te geven anders dan aan zijn werkgever is nl. komen te vervallen. Overigens sluit het ontwerp aardig aan op de gedachten van Louwers, want ook in het ontwerp ligt de gedachte verankerd: „wat in het besloten verkeer blijft, moet geacht worden niet openbaar te zijn gemaakt".

En dit is wel het meest opmerkelijke van het ontwerp met betrekking tot de accountant in dienstbetrekking. Hiermede wordt het besloten verkeer mede het werkterrein van de interne accountant.

Wij achten deze uitbreiding van het arbeidsterrein van de interne accountant een bedenkelijke zaak. Bedenkelijk achten wij het feit dat de interne accountant zich rechtstreeks kan wenden tot opdrachtgevers, anderen dan zijn werkgever, met de enige beperking dat hij erop bedacht moet zijn niet buiten het besloten verkeer te komen. Vanuit beroepsstandpunt gezien is dit niet alleen een ongewenste ontwikkeling maar principieel onjuist. In het vlak van de accountantsverklaring bestaat $\mathrm{nl}$. geen onderscheid tussen besloten en openbaar maatschappelijk verkeer. Elke accountantsverklaring, voorzover niet uitsluitend bestemd voor intern gebruik, moet inhouden een onafhankelijk oordeel en dat kan - functioneel gezien - alleen gegeven worden door de openbare accountant. Het maatschappelijk verkeer gaat er terecht van uit dat een verklaring in een onafhankelijke, onpartijdige sfeer tot stand is gekomen. Door zijn functionele gebondenheid aan de leiding van de onderneming kan de interne accountant deze zekerheid aan het verkeer niet overbrengen, noch 
aan het besloten, noch aan het openbaar maatschappelijk verkeer.

Zoals uit het bovenstaande duidelijk zal zijn geworden zijn wij er een voorstander van dat het oude artikel 21 lid 1 wordt gehandhaafd.

Nauw verbonden met het vraagstuk van de accountant in dienstbetrekking is de gevolgde indeling van het ontwerp in hoofdstukken. De indeling sluit aan op twee taken aan de Orde toevertrouwd, nl. de zorg voor de stand en bevordering van een goede beroepsuitoefening. Al datgene wat op de beroepsuitoefening betrekking heeft is terug te vinden in hoofdstuk II en slaat zowel op de openbare als op de in dienstbetrekking zijnde accountant, behalve dan art. 84 (alleen voor de openbare accountant).

Op de keper beschouwd is dit natuurlijk niet zo. De artt. 140 e.v. (openbaarmaking) zijn geschreven voor de openbare accountant, want alleen hij kan gedogen dat door hem afgegeven verklaringen openbaar worden gemaakt. Zij kunnen niet gelden voor de accountant in dienstbetrekking, omdat bij deze de in art. 150 bedoelde onafhankelijkheid ontbreekt. Dit weet hij zonder meer en hij behoeft zich daarom ook niet bezig te houden met de vraag of toestemming tot openbaar maken mogelijk is, omdat hij van tevoren weet dat hij aan de voorschriften van hoofdstuk II, en met name van art. 150 niet kan voldoen. Wij gaan uit van een objectief bepaalde functionele onafhankelijkheid, zoals trouwens ook in de toelichting op artikel 150 is aangegeven. Subjectieve inzichten in een al of niet aanwezige onafhankelijkheid kunnen uiteraard geen rol spelen.

Onze conclusie is, dat daar de artikelen betreffende de openbaarmaking, ook volgens het ontwerp, slechts gelden voor de openbare accountant, deze artikelen beter kunnen worden opgenomen in Hoofdstuk III. Wel zal dan in Hoofdstuk II dienen te worden opgenomen dat de accountant in dienstbetrekking er voor zorg draagt, dat zijn verklaringen niet openbaar worden gemaakt. (Zie art. 21 lid 1.)

\section{Het gebruik maken van verklaringen van andere accountants}

Het is reeds lang zo, dat de Nederlandse accountant voor zijn eigen verklaring gebruik kan maken van de verklaring van een andere accountant. Afgezien van de verklaring van een interne accountant doet zich dit voornamelijk voor in de situatie dat de concern-accountant voor zijn verklaring bij de jaarrekening van het concern gebruik makt van verklaringen van andere openbare accountants bij de jaarrekeningen van dochterondernemingen.

Wij zullen ons in het nu volgende voornamelijk bezighouden met het gebruik maken van de verklaring van een buitenlandse accountant omdat dit o.i. de meeste problemen opwerpt.

Vóór het in werking treden van de Regelen Beroepsuitoefening Registeraccountants (1963) waren hieraan, althans voor wat betreft de buitenlandse accountant, nauwelijks voorwaarden gesteld. Een aanvullend onderzoek was niet nodig; er moest slechts worden vastgesteld dat de buitenlandse accountant de praktijk in vrij beroep uitoefende en dat naar het oordeel van de accountant bij de keuze de nodige zorgvuldigheid werd betracht. 
Met het in werking treden van de R.B.R. deed de eis van het aanvullend onderzoek zijn intrede, een aanvullend onderzoek dat een deugdelijke grondslag voor de verklaring van de accountant moest geven. Deze eis is in het voorontwerp gedrags- en beroepsregels registeraccountants gehandhaafd. De eis van een aanvullend onderzoek geldt zowel in het geval dat gebruik wordt gemaakt van een verklaring van een registeraccountant als in het geval van gebruikmaking van een verklaring van een buitenlandse accountant. Indien wij te maken hebben met de verklaring van een registeraccountant zal veelal kunnen worden volstaan met een beoordeling van het controle-programma en beoordeling van de uitvoering door inzage van de dossiers. Het aanvullend onderzoek zal in het merendeel der gevallen niet nodig zijn. Dit ligt bij het gebruik maken van verklaringen van buitenlandse accountants bepaald anders, daar hier immers rekening moet worden gehouden met o.m. andere beroepsopvattingen.

$\mathrm{W}_{\mathrm{ij}}$ willen in het kader van dit onderdeel niet verder stilstaan bij het aanvullend onderzoek, maar onze aandacht meer richten op het vraagstuk in hoeverre het gebruik maken van verklaringen van andere accountants in de eigen verklaring moet worden opgenomen. Indien t.a.v. de registeraccountant gesteld kan worden dat een aanvullend onderzoek normaliter niet nodig is, respectievelijk een aanvullend onderzoek geen specifieke problemen zal opwerpen, dan is het zonder meer aanvaardbaar te achten dat in de verklaring van de concern-accountant vermelding achterwege blijft. Ten aanzien van de vermelding van het gebruik maken van de verklaring van een buitenlandse openbare accountant vermelden wij eerst enige meningsuitingen van de laatste jaren:

- Reglement van arbeid (art. 8)

- R.B.R. (art. 4.2)

- Rapport C.B.B. (1964)

- C.H.B. bulletin (5)

- U.G.B.R. (art. 83)

verplichte vermelding

geen vermelding"

keuze van al dan niet vermelden

Tussen de opvatting in het C.H.B. bulletin en het voorontwerp bestaat nog dit verschil, dat in het bulletin de aanbeveling wordt gedaan bij wel vermelden een indicatie te geven van de omvang van het deel van de verantwoording waarop het afgeleide oordeel betrekking heeft. Dit is door de C.H.B. in het voorontwerp niet overgenomen.

De meningsuitingen overziende vinden wij de meest strakke lijn in het rapport van de C.B.B. Indien de registeraccountant gebruik maakt van de verklaring van een andere accountant is hij verplicht (tenzij de overbodigheid is vastgesteld) een aanvullend onderzoek te verrichten, dat een deugdelijke grondslag voor zijn eigen verklaring legt (art. 5.1 R.v.A.). Indien de registeraccountant hieraan voldoet en hij is hiermede tot een deugdelijke grondslag voor zijn verklaring gekomen dan is de mededeling dat hij gebruik heeft gemakkt van de verklaring van een andere accountant volgens de commissie overbodig. Kan hij zich over bepaalde onderdelen van de jaarrekening, ook na het aanvullend onderzoek, geen voldoende oordeel vormen dan is hij 
gehouden een voorbehoud te maken. Met vermelding van het feit dat van verklaringen van andere accountants gebruik is gemaakt wordt van een niet aanwezige deugdelijke grondslag geen blijk gegeven.

Wil men de konsekwenties van het C.B.B. rapport niet aanvaarden dan doet men art. 5.1 R.B.R. respectievelijk art. 80 van het voorontwerp geweld aan. Als wij in onze regels vastleggen dat de arbeid van de accountant zodanig moet worden verricht dat een deugdelijke grondslag voor zijn verklaring wordt verkregen en dat het gebruik maken van de verklaring van een andere accountant uit dezen hoofde een aanvullend onderzoek vereist, dan wordt hiermede niet anders bedoeld dan dat de accountant verantwoordelijkheid moet kunnen dragen voor de gronden waarop hij de verklaring van een andere accountant aanvaardt. Kan hij dit, dan kan vermelding achterwege blijven, kan hij dit niet, dan heeft dit konsekwenties voor zijn verklaring.

In „Stramien" zegt Uiterlinden dat in vele gevallen niet verder kan worden gekomen dan een review, omdat het - wellicht hierop noodzakelijke - aanvullend onderzoek veelal op praktische gronden niet wel mogelijk is.

Die review leidt niet verder dan een afgeleid oordeel over de door de buitenlandse accountant gecontroleerde deelbelangen. Onder deze omstandigheden acht Uiterlinden verwijzing naar de verklaring van de buitenlandse accountant zinvol. Wij moeten roeien - zegt Uiterlinden - met de riemen die wij hebben. In menig geval betekent dit volgens hem, dat volstaan moet worden met een onvolkomen oordeel over buitenlandse deelbelangen.

Dit moge zo zijn, wij willen het zelfs niet tegenspreken, maar dan moeten wij wel beseffen dat wij niet meer kunnen leven naar de regels die wij ons zelf hebben gesteld. Onze arbeid moet een deugdelijke grondslag geven voor onze verklaring en die mag niet worden ondermijnd door een onvolkomen oordeel over buitenlandse deelbelangen. Dan zouden wij dit in onze verklaring tot uiting moeten brengen en kunnen we niet met een verwijzing naar het gebruik maken volstaan. Dat de vermelding van het gebruik maken van de verklaring van een andere accountant uitsluitend de betekenis heeft aan te geven dat de verklaring van de concern-accountant ten dele afgeleid tot stand is gekomen zal niemand aanspreken, zolang hij niet weet wat de wezenlijke betekenis hiervan is voor de verklaring. Hiermede zijn wij dan tot het voorontwerp gekomen. Uit de toelichting op artikel 83 blijkt dat met afgeleid tot stand komen bedoeld wordt dat het oordeel van de accountant voor een deel berust op het oordeel van andere accountants en niet op eigen onderzoek. Ik moet aannemen dat er een voldoende bewaking is geweest over het oordeel dat door de andere accountant is uitgesproken en dat de concern-accountant een deugdelijke grondslag heeft voor zijn verklaring betreffende de concernjaarrekening als geheel, hiermede aanvaardend de verantwoordelijkheid voor het beeld dat van het concern wordt gegeven.

Toch kan men - mede gezien de keuzemogelijkheid van al of niet vermelden - in de gekozen redaktie een - zij het niet bedoelde - beperking voelen van de verantwoordelijkheid van de concern-accountant. Deze beperking past niet in het raam van het voorontwerp, met name art. 80 verzet zich hiertegen. Vanzelfsprekend komt dan in de gedachte de oplossing die onze Amerikaanse beroepsgenoten hebben vastgelegd in Statement on Auditing 
Procedures no. 45 van juli 1971. Ook hier heeft de concern-accountant de keuze van wel of niet vermelden van het feit dat een deel is gecontroleerd door andere accountants, maar er zijn wel stringentere voorwaarden gesteld dan bij ons.

Voorzover voor ons onderwerp van belang kan de inhoud van S.A.P. 45 in het kort als volgt worden weergegeven.

Indien de concern-accountant tot het besluit komt in zijn verklaring niet op te nemen dat hij gebruik heeft gemaakt van de verklaring van een andere accountant, zal hij zich op de hoogte dienen te stellen van het gebruikte controleprogramma en inzage moeten nemen van de controle-dossiers. Voorts zal hij, waar nodig, een aanvullend onderzoek verrichten op door hem te bepalen onderdelen van de door de collega-accountant verrichte deeltaak.

Besluit de concern-accountant in zijn verklaring wel op te nemen dat hij gebruik heeft gemaakt van de verklaring van een andere accountant (hetgeen o.m. het geval kan zijn als de deeltaak van de andere accountant relatief groot is) dan kan review en aanvullend onderzoek achterwege blijven en kan worden volstaan met een onderzoek naar reputatie en onafhankelijkheid. Bij verwijzing in de verklaring dient echter duidelijk te worden aangegeven welk deel van de jaarrekening wordt gedekt door eigen onderzoek en welk deel door het onderzoek van de andere accountant. Van de omvang van de door de andere accountant verrichte deeltaak moet dus een indicatie in de verklaring worden opgenomen. $\mathrm{Er}$ is duidelijk sprake van een gedeelde verantwoordelijkheid.

Naar ons gevoelen sluit deze aanpak beter aan bij de inhoud van artikel 80 en bij de in de artikelen 81 en 82 opgenomen voorschriften. Indien de concern-accountant aan de inhoud van deze artikelen kan voldoen behoeft hij in zijn verklaring geen verwijzing op te nemen. Het opnemen van een verwijzing kan dan alleen nog maar de betekenis hebben dat hij de verantwoordelijkheid voor het geheel niet wil aanvaarden. Dit moet dan, evenals in S.A.P. 45, duidelijk in de verklaring worden gesteld.

Uit het bovenstaande mag niet de conclusie worden getrokken dat de door onze Amerikaanse collegae gevonden oplossing geheel bevredigt. Ook met een duidelijke afgrenzing van eigen onderzoek en het door andere accountants verrichte onderzoek zal het verkeer met deze verklaring niet goed raad weten. Zeker in die gevallen waar de deeltaak van de andere accountant relatief groot is ten opzichte van het geheel dient men er zich van bewust te zijn dat de betekenis van de verklaring van de concern-accountant is afgenomen, hetgeen ongetwijfeld afbreuk zal doen aan de duidelijkheid ervan.

Maar ook al is het geen ideale oplossing, wel wordt aan het verkeer duidelijker medegedeeld welke betekenis aan de verwijzing naar de verklaring van de andere accountant moet worden gehecht. Dit achten wij in vergelijking met de in het voorontwerp getroffen regeling, een verbetering.

\section{Nawoord}

Wij hebben met bovenstaande regels een vluchtige schets willen geven van 
enkele belangrijke, in de voorgestelde reglementering aangegeven, vraagstukken. Vluchtig in de zin van een opiniepeiling, die naar haar aard niet in details is uitgewerkt. Het is ten enen male niet mogelijk dieper te graven. Een speciaal nummer van dit maandblad zou nog onvoldoende ruimte bieden voor een grondige behandeling van alle professionele beginselen, die in het geding zijn.

Nochtans vleien wij ons met de hoop dat hetgeen is neergeschreven een bijdrage zal zijn in de verdere bezinning, die men ongetwijfeld met betrekking tot de herziening heeft voorgenomen en dat onze bijdrage daarin een structureel element zal vormen. 